\title{
地下空間浸水時における \\ 避難困難度指標とその適用 \\ CRITERION AND ITS APPLICATION FOR SAFETY EVACUATION \\ DURING UNDERGROUND FLOODING
}

\author{
大西良純 1 ・石垣泰輔 2 ・馬場康之 ${ }^{3}$ ・ 戸田圭一 4 \\ Yoshizumi ONISHI, Taisuke ISHIGAKI, Yasuyuki BABA, Keiichi TODA \\ 1学生員 関西大学大学院生 工学研究科（干564-8680 吹田市山手町3-3-35) \\ 2正会員 工博 関西大学教授 環境都市工学部 都市システム工学科（†564-8680 吹田市山手町3-3-35） \\ 3 正会員 工博 京都大学助教 防災研究所（干611-0011 宇治市五ヶ庄） \\ 4正会員 Ph. D. 京都大学教授 防災研究所（土611-0011 宇治市五ヶ庄）
}

\begin{abstract}
Risks of urban flood have been increasing in recent years. Heavy rainfalls that attacked Tokyo, Nagoya and Fukuoka cased the underground inundations. When the underground inundation occurs, people must evacuate to the ground as soon as possible. Therefore, it is necessary to evaluate when and where it becomes difficult for users to evacuate during the inundation. The difficulty of evacuation in stairs has been evaluated with momentum per unit width. However, this criterion can not be applied to a corridor. In this paper, specific force per unit width is introduced as a new criterion to evaluate safety evacuation in both cases. It is difficult to implement safety evacuation when the specific force per unit width is over $0.125 \mathrm{~m}^{2}$.
\end{abstract}

Key Words : urban flood, underground space, evacuation, momentum, specific force

\section{1. はじめに}

我が国における都市部の土地利用は，限られた場所を 有効に活用寸るため，高層住宅や高層ビルなどに見られ るように縦方向へと広がりを見せている. こうした縦方 向への広がりは「高層化」という概念だけでなく，「地 下空間の開発」という形にも現れている. 2001年4月に は「大深度地下の公共的使用に関寸る特別措置法」が施 行されており，都市部における地下空間利用はさらに拡 大される方向にある. 地下街や地下鉄などの地下施設は, 有効な土地利用という観点からだけでなく, 空調設備の 整った快適な空間，商業施設の並んだ便利な空間，車の 往来がない安全な空間として, 毎日多くの人に利用され ている.

都市化の進展は有用な地下空間の形成を促した一方で, 都市の保水・遊水機能を低下させた。 域内の雨水排除は 下水設備に依存するようになり，その排水能力を超える 降雨になると地上に水が汇濫するようになった．また， 近年では地球規模での気候変動に伴い，局地的な集中豪 雨の発生回数が増加しており, 時間雨量が100mmを超え る豪雨も珍しくはなくなってきた。 こうした激しい降雨
が都市部で発生すると，地盤の低い地下空間が浸水する 恐れがある。

1999年6月，九州北部で断続的に激しい雨が降り，御 笠川が汇濫するなど福岡市内で甚大な被害が発生した. 2000年9月には愛知・岐阜・三重県などの東海地方を中 心に集中豪雨が襲い，各地で床上・床下浸水や土砂災害 などの被害をもたらした．これらの降雨の際，福岡市や 名古屋市などの市街地では地下空間に汇濫水が流入し， 地下鉄が不通になるなど都市機能を麻痺させた．福岡市 では2003年に再び豪雨に見舞われ，博多駅周辺ではやは り地下浸水の被害が発生した。1999年6月に福岡市，同 年8月に新宿区で発生した豪雨では，水没した地下室に 閉じ込められた人が避難できずに亡くなっている.

こうした地下空間浸水時の危険性や避難に関寸る研究 は，模型実験や数值計算による避難シミュレーションな どを通して評価・検討が行われてきた ${ }^{1)}$.しかし，既往 の成果は地上への連絡路となる階段部, または平坦部に おける水中歩行の危険性がそれぞれに評価されていた. 本報では地下から地上への一連の避難について, その避 難困難度を同一の指標を用いて評価することを目的とし て新たな指標を作成し，その適用を試みた。 


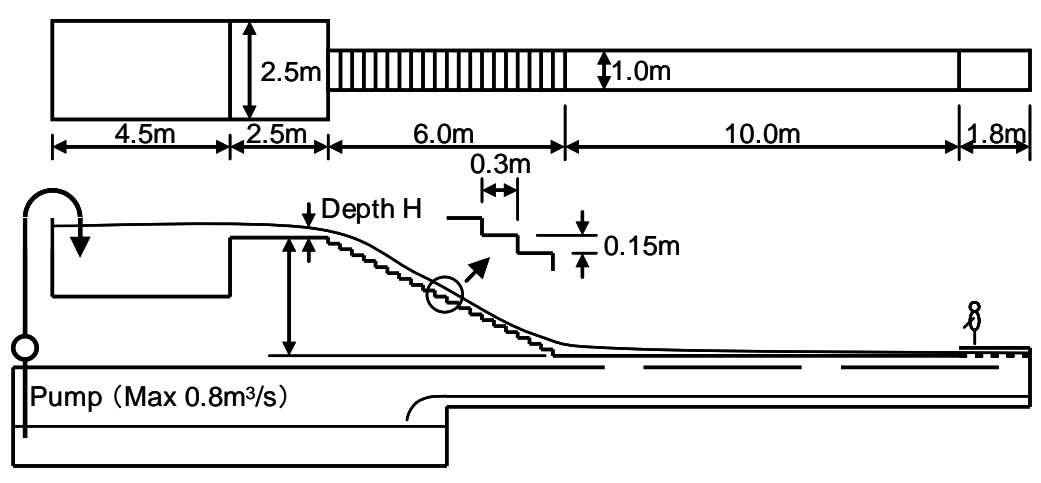

図-1 実物大階段模型

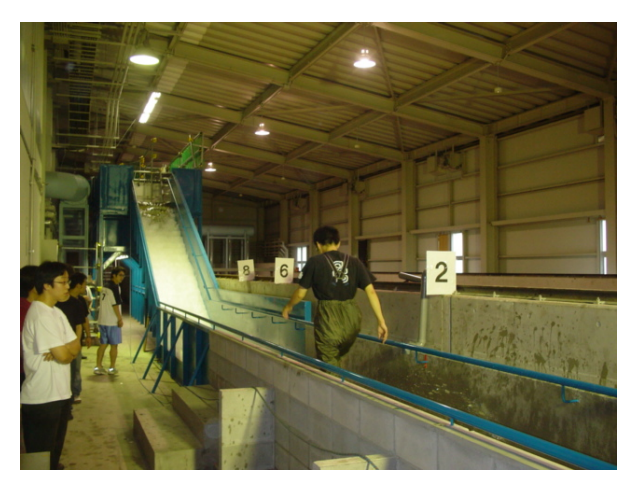

写真-1 避難体験実験の様子

\section{2. 実物大模型実験による避難困難度評価}

\section{（1）実験概要}

本研究では地下空間浸水時の避難困難度を定量的に評 価するため，実物大模型を用いた避難体験実験を実施し た. 実験に用いた階段模型は京都大学防災研究所宇治川 オープンラボラトリーに設置された図-1に示す装置であ る.この装置は高水槽, 地上部分を想定した $2.5 \mathrm{~m}$ 四方の

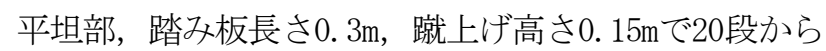
成る階段部，地下通路を想定した $10 \mathrm{~m} の$ 通路部より構成 されている. なお，水路幅は階段・通路部共に $1 \mathrm{~m}$ である. 避難体験実験の様子を写真-1に示す.

実験は地下空間への浸水を想定して行われているため, 階段最上段の水深（高水槽より越流する水深）を地上水 深 : Hとして条件設定を行っている. これを $\mathrm{H}=0$ 〜 $50 \mathrm{~cm} の$ 範囲で10cmごとに変化させ，流速・水深の測定および避 難体験実験を実施した．ただし，被験者の安全を確保す

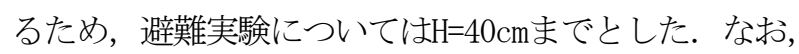
通路部最下流端には高さ調節可能な堰が設置されており, 堰高を変更することで通路部の水深を変化させることが 可能となっている. 本模型を用いた避難実験は過去にも 行われており，避難困難度の評価・検討が行われている 1).ただし，当時の実験模型は通路部が5mであったこと， 堰が設置されていなかったことなど，階段部における避 難に主眼を置いたものとなっている（2006年に模型の改 修工事が行われている)。なお，堰上げ無し条件下にお ける種々の実験結果は既報 ${ }^{1)}$ に記した通りである.

\section{（2）既往の研究成果}

石垣ら ${ }^{1)}$ によると, 被験者の歩行速度の変化や歩行時 の様子, 手すりの使用状況（原則として，危険であると 感じたとき以外は使用しない)，実験後に行われた被験 者対象のアンケートなどから， $\mathrm{H}=30 \mathrm{~cm}$ を超えると避難が 困難になるとの結論が導かれている．また，単位幅運動 量 : $\mathrm{u}^{2} \mathrm{~h}$ 用いて，これが $1.2 \mathrm{~m}^{3} / \mathrm{s}^{2}$ を超えると安全な避難 ができなくなるとの指標も提案されている. なお，この 評価指標の詳しい検討内容に関しては後述する.
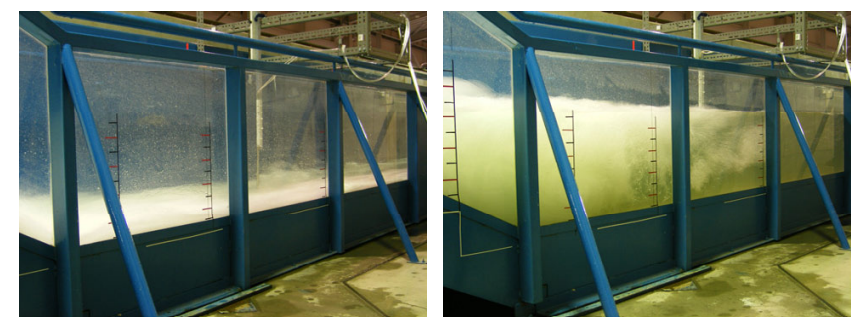

写真-2 堰上げ無し（左），堰上げ有り（右） ( $\mathrm{H}=20 \mathrm{~cm})$

表-1 堰上げ条件下における諸量

\begin{tabular}{|c|c|c|c|c|}
\hline 地上水深 & 堰高 & 通路水深 & 流速 & 歩行速度 \\
\hline \multirow{3}{*}{$20 \mathrm{~cm}$} & なし & $5.3 \mathrm{~cm}$ & $2.64 \mathrm{~m} / \mathrm{s}$ & $1.14 \mathrm{~m} / \mathrm{s}$ \\
\cline { 2 - 5 } & $30 \mathrm{~cm}$ & $48.8 \mathrm{~cm}$ & $0.30 \mathrm{~m} / \mathrm{s}$ & $0.65 \mathrm{~m} / \mathrm{s}$ \\
\hline \multirow{3}{*}{$30 \mathrm{~cm}$} & なし & $7.6 \mathrm{~cm}$ & $3.54 \mathrm{~m} / \mathrm{s}$ & $1.04 \mathrm{~m} / \mathrm{s}$ \\
\cline { 2 - 5 } & $20 \mathrm{~cm}$ & $43.2 \mathrm{~cm}$ & $0.80 \mathrm{~m} / \mathrm{s}$ & $0.78 \mathrm{~m} / \mathrm{s}$ \\
\cline { 2 - 5 } & $30 \mathrm{~cm}$ & $57.0 \mathrm{~cm}$ & $0.64 \mathrm{~m} / \mathrm{s}$ & $0.71 \mathrm{~m} / \mathrm{s}$ \\
\hline
\end{tabular}

\section{(3) 実験条件}

本報では既往の実験内容 ${ }^{1)}$ に，堰上げによる堪水状態 などの条件を付加し，通路部にも視点を置いた避難体験 実験を実施した．本条件は密閉された地下空間に水が流 入すると, 排水されずに水深が増大することを想定して いる．新たに追加した条件はH=20cmで堰高 $20 \mathrm{~cm}, H=30 \mathrm{~cm}$

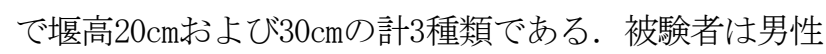
51名, 女性6名であり, 胴長を着用し模型からの避難完 了までに要した時間を計測した. なお，被験者は20代が 中心となっている. 避難開始から階段1段目に足が着地 するまでを通路部の歩行時間とし，それと同時に階段部 最上段に足が着地するまでを階段部の歩行時間として計 測している.

通路部における流速はピトー管を用いて計測し，水深 はスケールを用いて目視により計測した。 堰の有無によ りその影響が階段部まで達することはなかったため，階 段部の流速および水深については既往の成果 ${ }^{1)}$ を用いた.

\section{（4）実験結果}

\section{a）避難時間による比較}

まず，堰上げ条件下における通路部の流速および水深， 避難実験より得られた通路部における被験者の平均歩行 


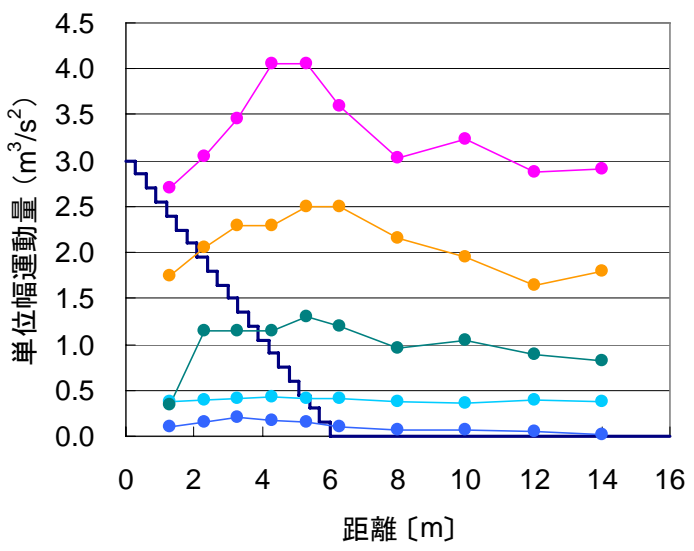

図-2 単位幅運動量による比較（堰無し）

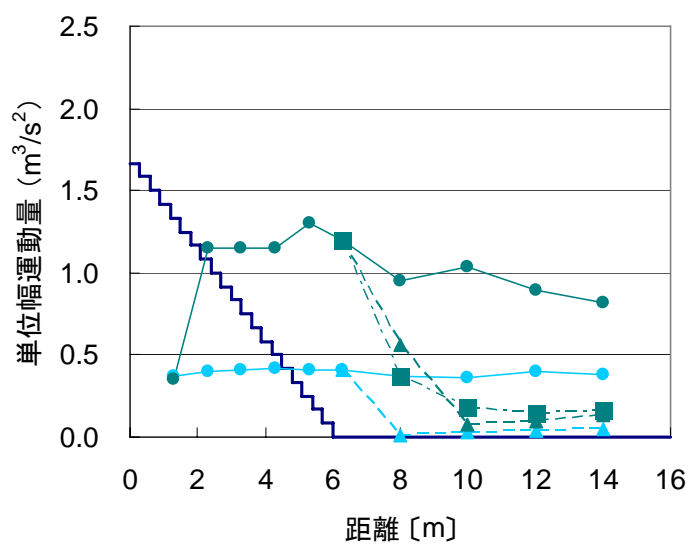

図-3 単位幅運動量による比較（堰有り）

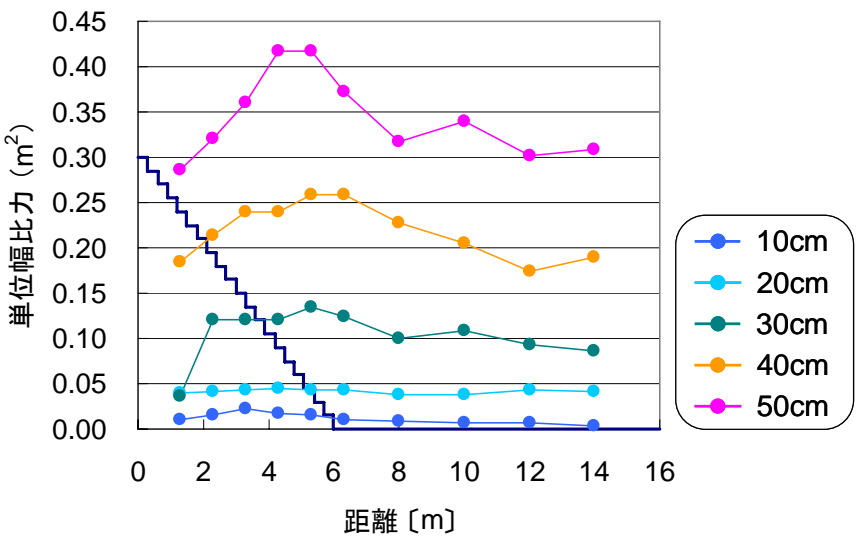

図-4 単位幅比力による比較（堰無し）

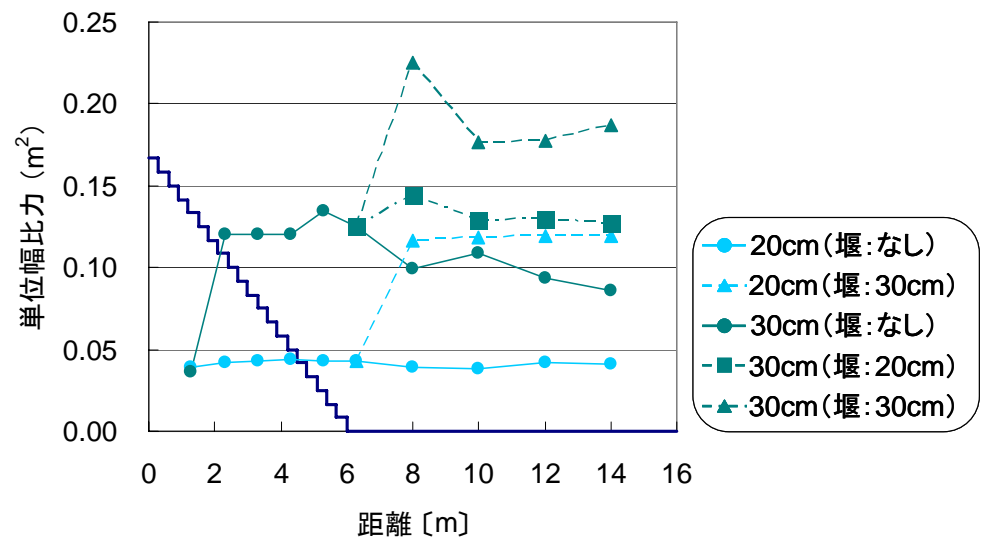

図-5 単位幅比力による比較（堰有り）
速度を表-1に示寸．また，堰の有無による通路部の様子 を写真-2に示す．これによると，堰上げ無し条件下では 通路部の水深が小さく, 流速が大きな值を示している. 一方，堰を設けた場合には通路部の水深が大きくなり流 速は低下した． $\mathrm{H}=20 \mathrm{~cm}$ の場合，堰上げ無し条件下では $1.14 \mathrm{~m} / \mathrm{s}$ であった歩行速度が， $20 \mathrm{~cm}$ 堰を設けることで ほぼ半分の $0.65 \mathrm{~m} / \mathrm{s} に な っ て い る 。 ま た ， ~ H=30 \mathrm{~cm} の$ 場合， 堰上げ無し条件下では $1.04 \mathrm{~m} / \mathrm{s}$ であった歩行速度は，堰 高 $20 \mathrm{~cm}$ の時には $0.78 \mathrm{~m} / \mathrm{s}$ ，堰高 $30 \mathrm{~cm}$ の時には $0.71 \mathrm{~m} / \mathrm{s}$ と なっている.このような歩行速度の低下が見られること から，通路部の水深が高い堰上げ条件下では，歩行が困 難になっていると考えられる．また，被験者の感想から も，水深の上昇により足に大きな負荷を感じていること が明らかとなった。

\section{b）単位幅運動量による検討}

図-2は階段模型に水を流下させた時の単位幅運動量 （以下，単に運動量と記す）：凱h（ただし，u：流速， $\mathrm{h}$ ：水深）を地上水深ごとに示したものである（凡例は 図-4 と共通)。図の横軸には階段最上段からの水平距離, 縦軸には単位幅運動量を示している。これによると，地 上水深が大きいほど模型全体を通して運動量が大きく なっている. また, 地上水深が大きくなるに従って, そ の増加の程度も大きくなっている．先に記したように，
既往の研究 ${ }^{1)}$ から「H=30cmで安全な避難の限界」とする 結論が得られているため, 図-2においてこの地上水深で 生じる $\mathrm{u}^{2} \mathrm{~h}=1.2 \mathrm{~m}^{3} / \mathrm{s}^{2}$ が安全な避難限界の指標として提案 されている.

次に，堰上げ条件下での運動量の様子を図-3に示寸 (凡例は図-5と共通)。乙れによると，同一の地上水深 に対する運動量は堰上げ時に小さくなっており, 避難困 難度は低下していると言える。しかし，表-1に見られる ように，堰上げの影響により歩行速度が減少しているこ とから，運動量ではこれを適切に評価できていないこと は明らかである．地上水深がどちらの場合も，堪水状態 における運動量は避難困難の指標とされた $\mathrm{u}^{2} \mathrm{~h}=1.2 \mathrm{~m}^{3} / \mathrm{s}^{2}$ を大きく下回っており，危険性が過小に評価されている と言える.

以上に示した通り，運動量を用いた避難困難度評価は 通路部においてその困難度を適切に表現できないという 問題点を抱えていることが明らかとなった. その理由と して，運動量は主に流速の大きさに依存していることが 挙げられる. 堰上げ無し条件下では階段部・通路部共に 高速流が生じるため, 運動量を同一の指標として用いる ことができた。一方，堰上げ条件下では通路部の水深上 昇に従い流速が低下したため, 避難困難度を適切に表現 寸ることができなかったと考えられる. 


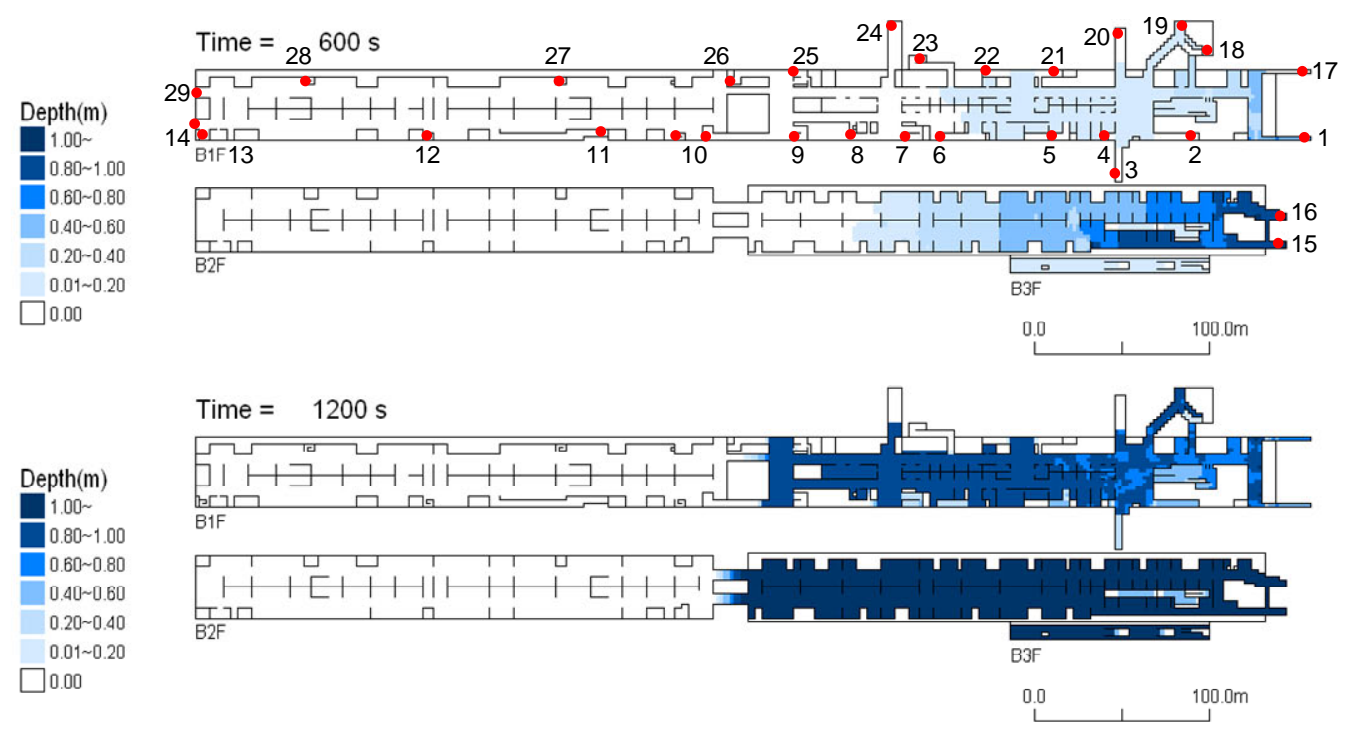

図-6＼cjkstart浸水深による評価

\section{c）単位幅比力による検討}

堰上げ時には水深が大きく上昇するため，流速よりも 水深（水圧）の影響が無視できなくなり，運動量では適 切な評価ができなかった，そこで，運動量に加えて水深 の大きさも表現できる単位幅比力（以下，比力と記 す）: $\mathrm{u}^{2} \mathrm{~h} / \mathrm{g}+\mathrm{h}^{2} / 2$ （ただし， $\mathrm{g}$ : 重力加速度）を用いて再 評価を行った。

図-4は図-2と同じ要領で，階段模型全体における比力 を示したものである.これによると，值の大きさこそ異 なるものの, グラフの形状自体は図-2とほぼ相違ない. ここでも，「H=30cmが安全避難の限界」であるとのこと から, $\mathrm{u}^{2} \mathrm{~h} / \mathrm{g}+\mathrm{h}^{2} / 2=0.125 \mathrm{~m}^{2}$ を避難困難度の指標として見 ることができる，また，堰上げ条件での比力を図-5に示 す。これによると， $\mathrm{H}=20 \mathrm{~cm}$ では堰上げ時の方が比力は大 きくなっており, 避難が困難であるとの評価が現れた. $\mathrm{H}=30 \mathrm{~cm}$ においても, 堰高が大きくなるに従って, 比力の 増大と歩行速度の減少が見られ, 避難困難度の大小が適 切に表現できていると言える.

従来, 須賀ら ${ }^{2)}$ は水害発生時の避難を想定し, 大型水 路を用いた水中歩行に関する研究を行っている．それに よると水中歩行時における計画避難最低歩行速度は $0.40 \mathrm{~m} / \mathrm{s}$ 程度であるとの結論が導かれている. 本研究で は「安全避難」の限界を基準としたため, これよりも大 きな歩行速度で比力が0. $125 \mathrm{~m}^{2}$ を超えている.

以上より, 比力を用いた避難困難度指標の妥当性を示 すことができた.

\section{3. 氾濫計算における避難困難度指標の適用}

\section{（1）汇濫計算による検討}

一般的に洪水氾濫計算ではハザードマップなどにも見
表-2 流入条件

\begin{tabular}{|c|c|c|c|}
\hline 入口番号 & 流入開始時刻 & 流入流量 $\left(\mathrm{m}^{3} / \mathrm{s}\right)$ & 地上水深 $(\mathrm{m})$ \\
\hline 1 & 00分00秒 & 1.58 & 0.60 \\
\hline $15+16$ & 06分18秒 & 14.08 & 1.02 \\
\hline 3 & 10分03秒 & 1.32 & 0.33 \\
\hline 5 & 10分14秒 & 2.13 & 0.46 \\
\hline 4 & 10分30秒 & 1.88 & 0.42 \\
\hline 2 & 10分47秒 & 2.63 & 0.53 \\
\hline $18+19$ & 11分25秒 & 0.38 & 0.15 \\
\hline 6 & 11分53秒 & 1.31 & 0.33 \\
\hline 17 & 12分42秒 & 2.00 & 0.70 \\
\hline 7 & 14分09秒 & 1.08 & 0.29 \\
\hline 9 & 23分06秒 & 1.10 & 0.30 \\
\hline 10 & 24分01秒 & 0.54 & 0.18 \\
\hline 8 & 24分28秒 & 0.94 & 0.27 \\
\hline 11 & 27分08秒 & 0.67 & 0.21 \\
\hline 合計 & & 31.63 & \\
\hline
\end{tabular}

られるように，浸水深の分布によって汇濫時の危険性を 想定することが多い. しかし，先に記したように避難と いう観点から考えた場合には，浸水深分布とは異なる危 険度評価が表れると考えられる，そこで，本報では地下 空間における浸水時を想定し, 浸水深分布, 単位幅運動 量および単位幅比力を用いてその結果を比較・検討する.

\section{（2）計算対象地域}

本研究では正方格子を用いた氾濫計算モデルにより, 洪水氾濫計算を行った。 このモデルは対象地域を正方格 子に区切ることにより計算を行う手法であり，座標を規 則的に入力することができるため, 汇濫計算の中でも広 く一般的に用いられている方法である (図-6参照, 図中 の数字は出入口番号).

計算の対象地域は京都市中京区御池地下街とした。御 池地下街は御池通りの地下に位置し, 地下3層構造と なっている。地下 1 階は東側（図中，右側半分）が 


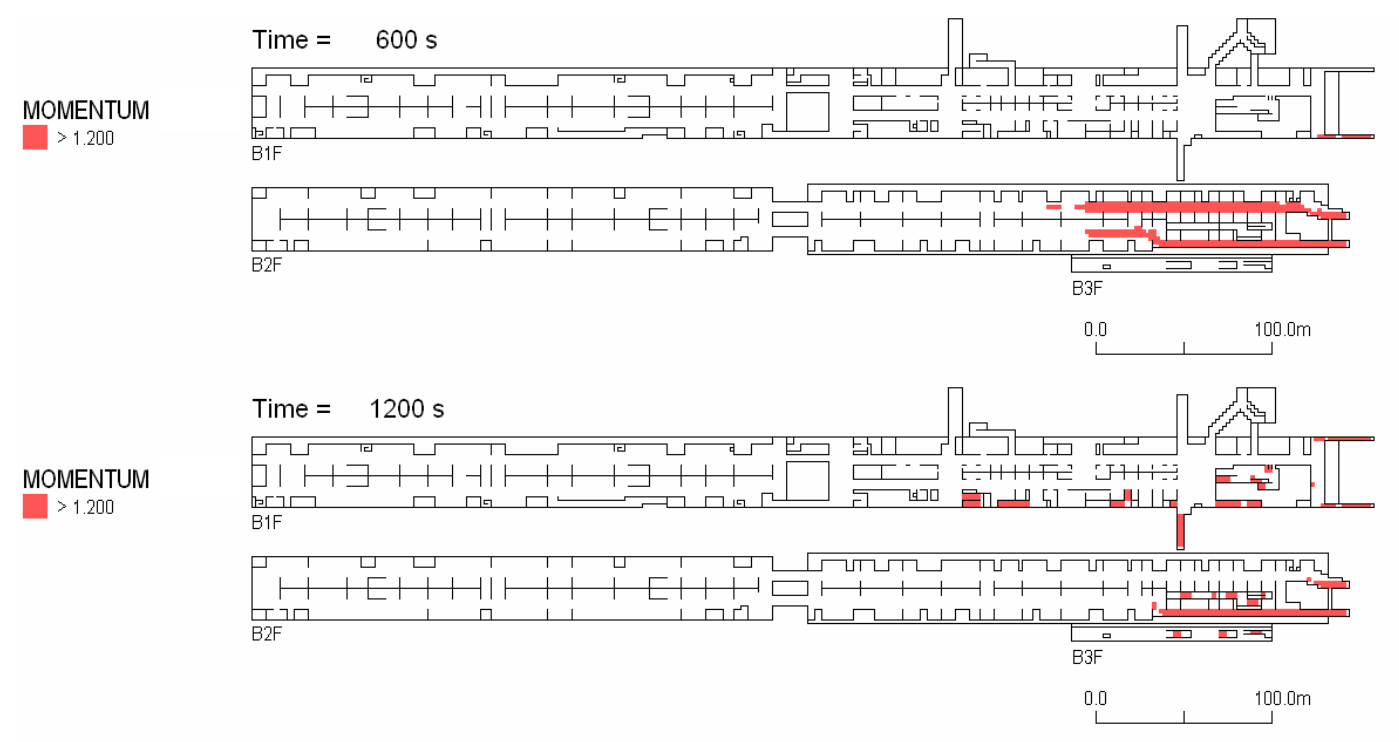

図-7 単位幅運動量による評価

ショッピングモール，地下1階西側と地下2階は駐車場と なっている. また, 両階とも東西約 $650 \mathrm{~m}$, 南北約 $40 \mathrm{~m}$, 天井高は $3.5 \mathrm{~m}$ であり，東側半分は西側よりも底面が $1.5 \mathrm{~m}$ 低くなっている，地下3階は東西約 $100 \mathrm{~m}$, 南北約 $8 \mathrm{~m}$ の長 方形で，京都市営地下鉄のホームとなっている. 天井高 は2.7mであるが利用客の線路内転落防止のため, 高さ 2. $4 \mathrm{~m}$ 直立壁が設置されている.この壁は列車発着時の み屝が開く構造であり，列車のいない時間は壁と天井の 小さな開口部以外は密閉に近い状態となっている.

地上と地下1階を結ぶ通路は歩行者専用階段およびエ スカレータが24箇所, 車両用出入り口が3箇所存在する. また，地上と地下2階を結ぶ通路は東側の車両用出入り 口が2箇所，地下1階と地下2階を結ぶ通路は西側に2箇所 の車両用スロープが存在する. 地下3階の地下鉄ホーム へは地下1階コンコースからのみの接続となっている.

本報では汇濫計算の精度を確認するため, 京都大学防 災研究所宇治川オープンラボラトリーに設置された縮尺 1/30の御池地下街模型による実験結果 ${ }^{3)}$ と比較した.

\section{（3）計算条件}

本報では，京都市市街地を対象として行われた縮尺 1/100模型を用いた水理実験結果 ${ }^{4)}$ を基に，御池地下街 に流入する流量を決定した. 表-2は流入条件を示してい るが，これはフルードの相似則により原型量に換算した ものを記載している。 また，流入開始時刻は1番出入口 からの流入が開始した時刻を0秒としている.

\section{（4）計算結果}

\section{a）浸水深による評価}

図-6は流入開始 $10 ， 20$ 分後の浸水深を示したものであ る（上段が流入開始 10 分後，下段が 20 分後）。これによ ると, 流入開始から10分後には地下1階の東側約半分と
地下 2 階の東側約 $2 / 30$ 範囲で浸水している．流入量の多 い地下2階では水深が $40 \mathrm{~cm}$ 超える範囲も見られ, 避難 体験実験においては堰上げ条件時の水深に相当するもの となっている。また，地下 3 階でも $20 \mathrm{~cm}$ 程度の浸水が見 られる。流入開始20分後には地下1，2階の浸水域は地盤 の低い東側全面に広がっており，地下3階も含めて広い 範囲で $80 \mathrm{~cm}$ 以上の水深となっている.

\section{b）単位幅運動量による評価}

次に，単位幅当たりの運動量を用いて汇濫の様子を示 す. 図-7は図-6と同様に流入開始後 10,20 分後の運動量

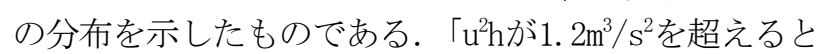
避難が困難」がこれまでの指標であったが，10分後には 地下2階東側の通路部でこの基準を上回る值が算出され ている. 20 分後には氾濫水の流入する階段付近では $\mathrm{u}^{2} \mathrm{~h}>1.2 \mathrm{~m}^{3} / \mathrm{s}^{2}$ となり，その危険度を適切に評価できてい ると考えられる。しかし，通路部においては10分後の值 よりも小さくなっている場所が存在する. これは水が溜 まることによって，流速が大きく低下したことが原因で あると考えられる. なお，計算時間をさらに延長すると， 水深のある程度上昇した場所では運動量が徐々に低下寸 る傾向が見られた．また，水深が $80 \mathrm{~cm}$ 超えるような状 況（図-6）が安全であるとは到底考えられず，運動量を 安全避難の指標として用いるのは適切でないと言える.

\section{c）単位幅比力による評価}

3つ目の評価方法として, 避難体験実験の避難困難度 評価と同様に単位幅当たりの比力を算出した. それによ り表現したものを図-8（記載方法は図-6，7に準じる） に示す. なお，先に示した基準の他に，堰上げ条件下で の避難実験において最大約 $0.200 \mathrm{~m}^{2}$ を超える比力を示し ため, 数值計算においてもその領域に分類して表示した. これによると10分後には地下2階東側で比力が $0.125 \mathrm{~m}^{2}$ を 超える領域が見られる. 20分後には地下1，2階東側全域 


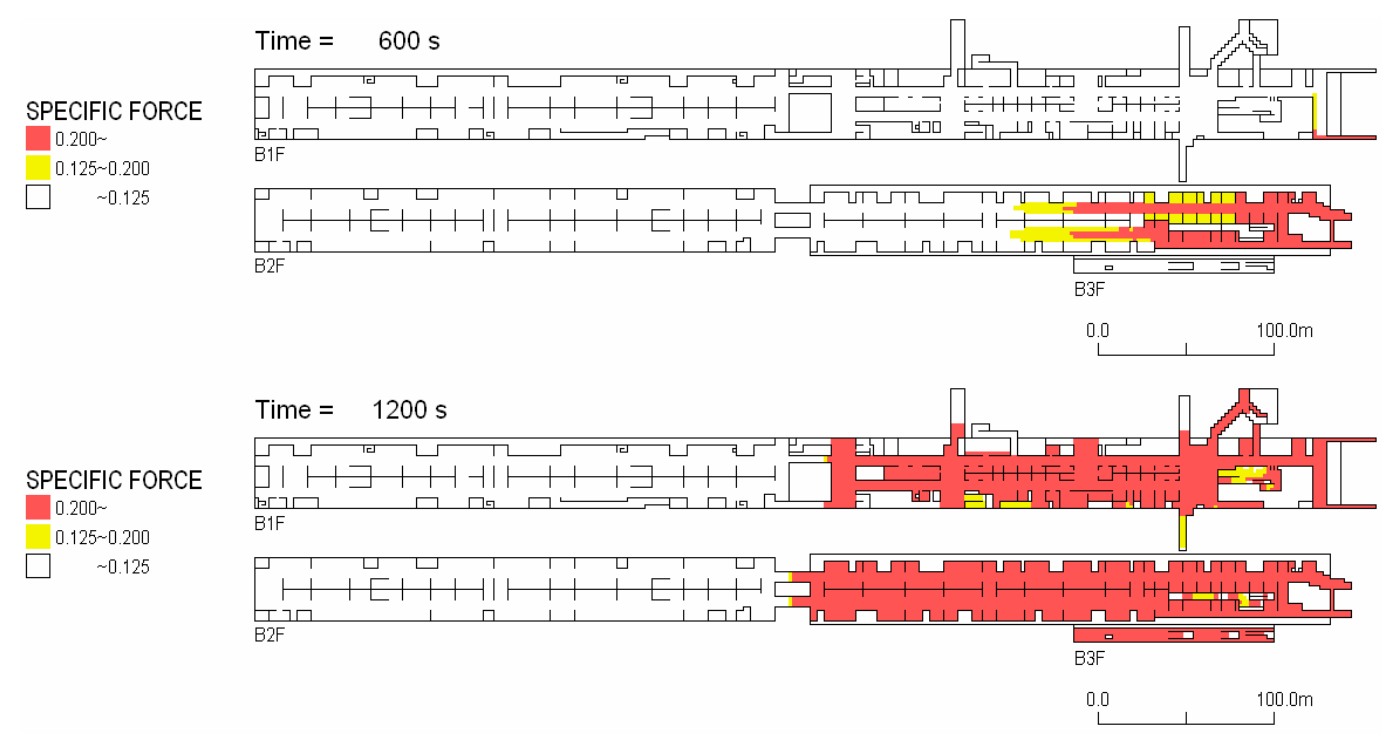

図-8 単位幅比力による評価

と地下3階で基準を超えており，避難が困難であるとの 状況が示された.

亀井 ${ }^{5)}$ によると，洪水時において平坦部の水深が成人 男性で $70 \mathrm{~cm}$ 以上，成人女性で $50 \mathrm{~cm}$ 以上になると歩行が困 難になるとされている．また，図-6において水深がそれ ぞれの值を超える領域では, 図-8においても比力が 0. $125 \mathrm{~m}^{2}$ を超えており, 歩行が困難であるとの状況を示 した．また，図-6においては階段部での水深が低くなっ ており，その危険度を判断するのは困難であったが，比 力を用いることで階段部も避難が困難であるとの評価が 表れた。 これにより通路部および階段部の避難困難度を 同一の指標で評価することができたと言える.

以上のことから, 地下空間浸水時の避難困難度を評価 するためには，運動量を用いるよりも比力により検討を 行う方が適切であると考えられる.

\section{4. おわりに}

本報では地下空間浸水時の避難困難度評価指標に関し て, 従来の問題点を改善するため, 新たな指標として単 位幅比力を導入し, 改めて検討を行った. 本研究で得ら れた成果を以下に簡潔に示す。

1）単位幅運動量を用いた評価指標（ $\left.\mathrm{u}^{2} \mathrm{~h}=1.2 \mathrm{~m}^{3} / \mathrm{s}^{2}\right)$ は流 速に依存した值が得られるため, 水深が大きい堪水 状態の避難困難度を適切に評価することができない，

2）単位幅比力を用いることで，地下空間浸水時の通路 および階段における避難困難度を同一の指標で評価 することが可能である. また, その時の単位幅比力 は $\mathrm{u}^{2} \mathrm{~h} / \mathrm{g}+\mathrm{h}^{2} / 2=0.125 \mathrm{~m}^{2}$ である.

3）比力を用いた評価指標を汇濫計算などにも適用する ことで，各地点における避難困難度の大小を明示寸

\section{ることができる.}

本報では地下空間浸水時における危険性を，「避難行 動」に着眼点を置いて検討を行った，その結果，地下空 間浸水時の避難困難度評価には比力の適用が望ましいと いうことが明らかとなった．また，比力を用いることで 危険箇所を容易に把握できること，より現実性の高い避 難シミュレーションが可能であることなどのメリットも 考えられる.こうした成果を用いて，避難活動に携わる 側（地下街管理者など）が避難計画を作成することが可 能である，ただし，避難計画は災害時要援護者など避難 がより困難になると予想される人に対して基準を合わせ る必要がある. その中に含まれる高齢者の避難困難度に 関しては, 現在も研究を行っているところである.

最後に，避難体験実験およびデータの計測・集計にご 協力頂いた方々に感謝の意を表します.

\section{参考文献}

1）石垣泰輔・戸田圭一・馬場康之・井上和也・中川一：実物 大模型を用いた地下空間からの避難に関する実験的検討, 水工学論文集, 第50巻, pp. 583-588, 2006.

2）須賀堯三 -上阪恒雄 - 白井勝二 ・ 高木茂知 - 浜口憲一郎 陳志軒 : 避難時の水中歩行に関する実験, 水工学論文集, 第38巻, pp. 829-832, 1994.

3）戸田圭一・井上和也 - 大八木亮 - 中井勉 - 竹村典久 : 複雑 な地下空間の浸水実験, 水工学論文集, 第48巻, pp. 583588, 2004.

4）石垣泰輔・中川一・馬場康之・技術汇濫模型実験グルー プ : 地下空間を含む都市洪水汇濫に関する水理模型実験, 京都大学防災研究所年報, 第47号B, pp. 527-544, 2004.

5）亀井勇：台風に対して，天災人災 住まいの文化誌，ミサ ワホーム総合研究所, 1984.

(2007.9. 30 受付) 